\title{
Benefits of effective diagnosis on impact of quality of life
}

\author{
Anthony T Dubois \\ From Food Allergy and Anaphylaxis Meeting 2011 \\ Venice, Italy. 17-19 February 2011
}

Quality of life has become a central outcome measure in medicine over the last two decades as it is increasingly being recognized that quality of life methodology is the most appropriate outcome measure with which to answer the question: does a particular management strategy provide clinically meaningful benefits as perceived by the patient? While the first of such studies in the area of food allergy were qualitative in nature, validated instruments have recently been developed in the context of the Europrevall study which measure healthrelated quality of life (HRQL) in a specific and reliable way. Instruments are now available for adults, adolescents and younger children of all ages. These instruments allow researchers and clinicians to quantitatively assess management strategies for food allergy Despite the fact that there is no cure for food allergy at the present time, management of many patients is thought to result in reduced risk and hence improved HRQL. There are many aspects to the management of the food allergic patient, including accurate diagnosis, adequate patient education, and provision of emergency medication where appropriate. All these elements may contribute to HRQL changes seen in patients with food allergy. Studies on the effects of effective diagnosis in the form of (double blind, placebo controlled) food challenges show that HRQL improves in patients undergoing this procedure. Although this improvement is greater in patients in whom the allergy is shown to be absent than in patients in whom the food allergy is confirmed, all patients show improvement in HRQL after having undergone this test. Thus, effective diagnostic testing is important to patients as it has a positive effect on HRQL. This effect is probably the result of diminished uncertainty that patients have about their disease resulting from the test.

\footnotetext{
Beatrix Children's Hospital, Department of Pediatric Pulmonology and
} Pediatric Allergy, Groningen, Netherlands
Published: 12 August 2011

doi:10.1186/2045-7022-1-S1-S75

Cite this article as: Dubois: Benefits of effective diagnosis on impact of quality of life. Clinical and Translational Allergy 2011 1(Suppl 1):S75.
Submit your next manuscript to BioMed Central and take full advantage of:

- Convenient online submission

- Thorough peer review

- No space constraints or color figure charges

- Immediate publication on acceptance

- Inclusion in PubMed, CAS, Scopus and Google Scholar

- Research which is freely available for redistribution

Submit your manuscript at www.biomedcentral.com/submit

\section{() Biomed Central}

